\title{
RADIOCARBON CHRONOLOGY FOR PREHISTORIC COMPLEXES OF THE RUSSIAN FAR EAST: 15 YEARS LATER
}

\author{
Yaroslav V Kuzmin \\ Institute of Geology \& Mineralogy, Siberian Branch of the Russian Academy of Sciences, Koptyug Ave. 3, Novosibirsk \\ 630090, Russia. Email: kuzmin@fulbrightmail.org.
}

\begin{abstract}
The recent progress in radiocarbon dating of the prehistoric cultural complexes in the Russian Far East is discussed against the background of ancient chronologies for greater East Asia. Since 1997, the wide use of accelerator mass spectrometry (AMS) radiocarbon dating along with the continuation of conventional dating has allowed us to establish the age of several key Paleolithic, Neolithic, and Paleometal sites. It has also contributed to advancing a deeper understanding of the timing for the beginning of pottery production, maritime adaptation, and agriculture, and several other important issues in prehistoric chronology for the studied region. Reservoir age correction values for the Japan and Okhotsk seas are now used to adjust the age for samples of marine origin. Some of the cultural-chronological models for prehistoric far eastern Russian complexes put forward in the last $10 \mathrm{yr}$ lack a solid basis, and are critically evaluated herein.
\end{abstract}

\section{INTRODUCTION}

The first chronological comprehensive framework for prehistoric (both Paleolithic and Neolithic) cultural complexes of the Russian Far East, including relatively extensive lists of radiocarbon dates and their critical analysis, was created in the mid-late 1990s (e.g. Kuzmin et al. 1994, 1998a). It was revised and amended until the early 2000s (e.g. Kuzmin 2006a). However, in the late 1990s it became clear that much more work is needed to construct a more reliable chronological scheme for the Stone Age and Paleometal complexes. Due to the limitation of sample size at many sites, the use of accelerator mass spectrometry (AMS) ${ }^{14} \mathrm{C}$ dating was necessary; however, as of now (August 2012) there are no AMS machines in Russia that can reliably measure ${ }^{14} \mathrm{C}$ content in samples of unknown age. Thus, in order to conduct this research, an informal agreement between the author and the NSF-Arizona AMS Laboratory (University of Arizona, Tucson, Arizona, USA) was achieved in 1997. Some other AMS laboratories in Japan, the Netherlands, and the Republic of Korea also participated in this research, as well as numerous Russian archaeologists who supplied material for ${ }^{14} \mathrm{C}$ dating. The conventional ${ }^{14} \mathrm{C}$ dating (conducted mainly in Novosibirsk laboratory, lab code SOAN; see Table 1) was continued to be employed when possible.

The main strategy was to obtain as many ${ }^{14} \mathrm{C}$ dates as possible from key sites of the Paleolithic, Neolithic, and Paleometal periods, and to supplement these with paleoenvironmental information. Also, the correlation with neighboring regions of greater East Asia was necessary to determine the place of the far eastern Russian cultural complexes in a wider context. Today, it is possible to summarize the results obtained over the last 10-15 yr and to discuss their impact on the existing chronology of the prehistoric Russian Far East. It is also timely to evaluate some models and conclusions on ancient chronology and environment of the region that have been put forward in the last decade or so and in my opinion cannot be substantiated according to modern methodological standards in geoarchaeology (e.g. Renfrew and Bahn 2004:231-74).

\section{MAIN ACHIEVEMENTS IN PREHISTORIC CHRONOLOGY OF THE RUSSIAN FAR EAST FOR THE LAST 10-15 YEARS: AN OVERVIEW}

\section{Paleolithic Chronology}

In order to understand the timing of the earliest Upper Paleolithic, dating of key sites (Figure 1, A) was performed. The ${ }^{14} \mathrm{C}$ values from the Geographic Society Cave, the oldest site in the Russian Far East with preservation of material for dating, generally fall into an interval from $>40,000$ to

(C) 2012 by the Arizona Board of Regents on behalf of the University of Arizona

Proceedings of the 6th International Radiocarbon and Archaeology Symposium, edited by E Boaretto and N R Rebollo Franco RADIOCARBON, Vol 54, Nr 3-4, 2012, p 727-736 
$\sim 31,500$ BP (Kuzmin et al. 2001). The specimens most closely associated with artifacts are in the range of $>38,000-40,000 \mathrm{BP}$; this age can be used as a provisional determination of the first appearance of humans in the southern part of the region. Other potentially early Paleolithic sites in the Russian Far East either have an unclear stratigraphic context (such as the Osinovka site in Primorye [Maritime] Province, see Derevianko and Tabarev 2006; the Filimoshki, Ust Tu, and Novorybachii sites in the Amur River basin, see Derevianko et al. 2006; and the Sennaya 1 site on Sakhalin Island, Vasilevsky 2008; see Kuzmin 2011:168) or were found on the surface (e.g. the Kumara cluster and Tambovka site, see Derevianko et al. 2006). Thus, their position is not secure enough to be considered as solid evidence about the human presence at a certain time, and thus, the Geographic Society Cave is the best early site so far in terms of its integrity.

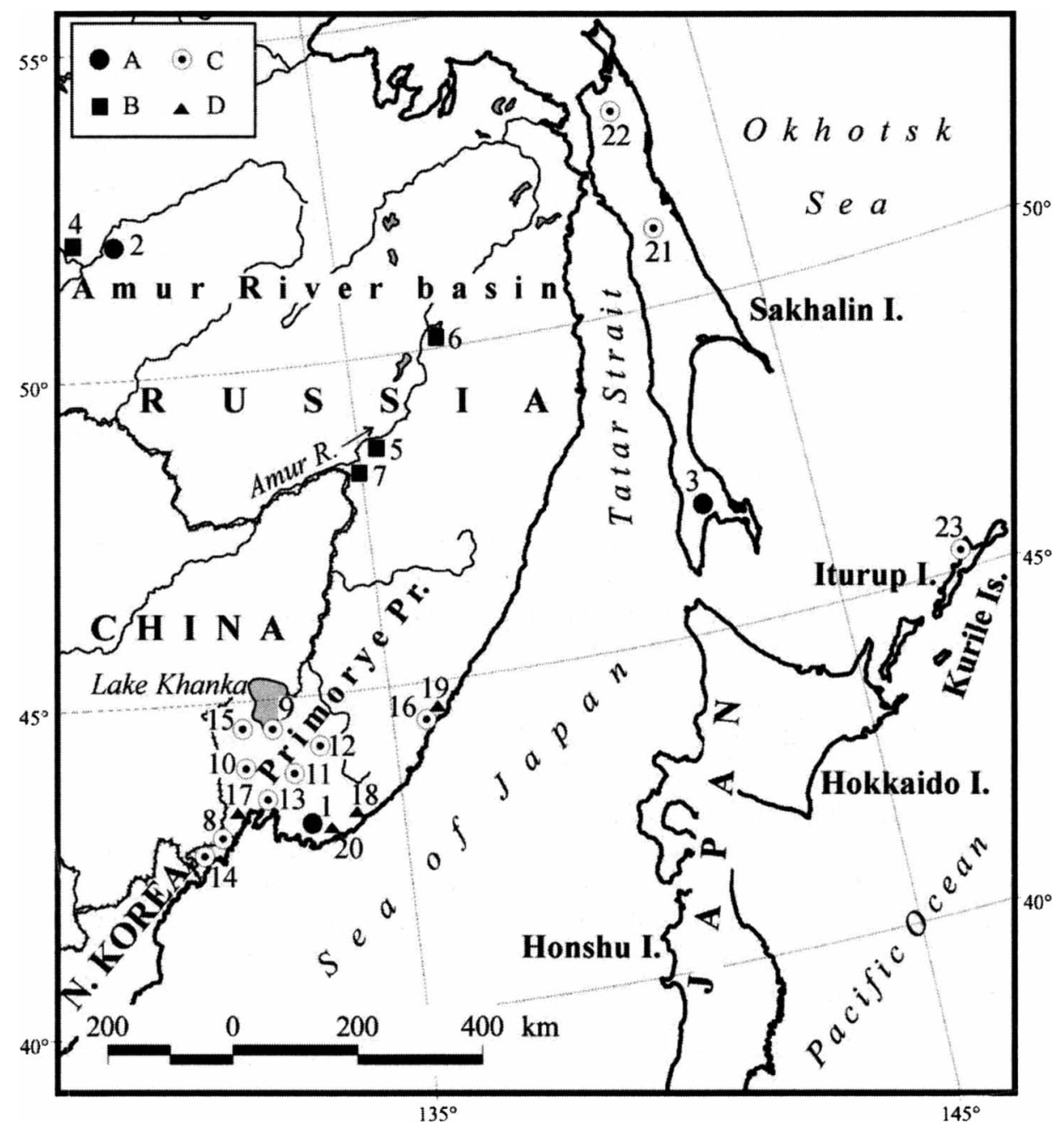

Figure 1 Key archaeological sites mentioned in the text. Epochs: A - Paleolithic; B - Initial Neolithic; C - Middle/Late Neolithic; and D - Paleometal. Sites: 1) Geographic Society Cave; 2) Ust-Ulma 1; 3) Ogonki 5; 4) Gromatukha; 5) Gasya; 6) Khummi; 7) Goncharka 1; 8) Boisman 1 and 2, Klerk 5; 9) Luzanova Sopka 2; 10) Krounovka 1 and Bogolubovka 1; 11) Mustang and Rettikhovka-Geologicheskaya; 12) Sheklyaevo 7; 13) Kirovsky; 14) Gvozdevo 4, Zaisanovka 1 and 7; 15) Novoselische 4; 16) Rudnaya; 17) Peschany; 18) Glazkovka 2, Zarya 3A and 3B; 19) Monastyrka 2 and 3; 20) Preobrazheniya 1; 21) Puzi 2; 22) Bolshaya Rechka 7; 23) Yankito. 
The microblade technology in northern Asia is a clear manifestation of the late Upper Paleolithic (e.g. Kuzmin 2007). In the Russian Far East, the earliest cultural component with microblades and wedge-shaped microcores, Layer $2 b$ of the Ust-Ulma 1 site in the Amur River basin, is dated to $\sim 19,400$ BP (e.g. Kuzmin 2007). Below it, there is another component, Layer 3, which also contains microblades but it is currently undated; the age estimate is $\sim 24,000-20,000 \mathrm{BP}$ (Derevianko et al. 2006). At another site in the Amur River region, Khodulikha 2 (not included in Figure $1 ; 50^{\circ} 40^{\prime} \mathrm{N}$, $127^{\circ} 20^{\prime} \mathrm{E}$ ) west of Ust-Ulma 1 site, the layer with microblades is dated to $\sim 16,500 \mathrm{BP}$ while below it the cultural component without traces of microblade technology has an age of $\sim 22,500 \mathrm{BP}$ (Kuzmin et al. 2005). The end of the Upper Paleolithic in the Russian Far East can now be dated to $\sim 11,500-10,300$ BP (Kuzmin 2003). The latest Paleolithic sites coexisted with the earliest Neolithic complexes with pottery (see below).

Recent progress in the study of microblade technology in Northeast Asia allows us to establish the age of the first appearance of microblades in Japan ( 21,000 BP; Hokkaido Island) and Korea ( 24,000 BP) (see Kuzmin 2007). This is similar to the Russian Far East and coincides in general with the Last Glacial Maximum (LGM). However, it would be premature to connect the appearance of microblade technology with climatic fluctuations around the LGM time (e.g. Goebel 2002). In Siberia and Mongolia, the earliest evidence of microblades (produced by pressure flaking) goes back to about 35,000-28,500 BP (e.g. Keates 2007; Kuzmin 2007; Derevianko 2009; Gladyshev et al. 2010) and definitely precedes the LGM, contra to Kuznetsov (2010) who still determines the age of microblade complexes in Siberia and East Asia as 24,000-10,000 BP.

\section{The Emergence of Pottery}

Pottery in East Asia and Siberia manifests the beginning of the Neolithic (e.g. Kuzmin 2006b). For a long time, Japan was considered the "cradle of pottery-making" with the age of the Incipient Jomon pottery complexes at $\sim 12,700-12,200$ BP (e.g. Morlan 1967). However, the first final Pleistocene ${ }^{14} \mathrm{C}$ dates for pottery assemblages of the Russian Far East were obtained in the early 1980s (Okladnikov and Medvedev 1983), but they were taken into consideration with a high degree of skepticism, especially in Japan. A program of dating the cultural layers of the Initial Neolithic sites in the Amur River basin (see Figure 1B) was set up in the mid-1990s. Extensive dating of charcoal and organic-tempered pottery resulted in the determination of its age as $\sim 13,300-12,300 \mathrm{BP}$ (O'Malley et al. 1999; Kuzmin 2003, 2006b; Nesterov et al. 2006). Finally, these values have been accepted by the international scholarly community (e.g. Boaretto et al. 2009).

It seems that there were 3 major independent centers of pottery origin in East Asia and worldwidesouthern China, Japan, and the Russian Far East - without clear traces of possible interaction and exchange of ideas and technology. There is no clear connection between the emergence of pottery and climatic changes in the Late Glacial (see review: Kuzmin 2010), and at the current stage of research we can only guess what was (were) the driving force(s) for the invention of pottery. This is the model of pottery emergence created by the author (see Kuzmin 2006b, 2010).

\section{The Origin of Maritime Adaptation}

The maritime adaptation of prehistoric coastal people in Northeast Asia was an important event in the economic history of the region. The increase of food resources, especially ones with predicted availability (such as shells from mollusk beds in shallow lagoons), was crucial for human survival. The first fully fledged maritime-adapted cultural complex in the Russian Far East is the Boisman culture in the southern Primorye, with Boisman 2 representing the key site (see Figure 1, C). Initial dating of this unique archaeological object was conducted in the early 1990s (Jull et al. 1994). Later 
on, more ${ }^{14} \mathrm{C}$ dates on charcoal, mammal bones, mollusk shells, and human bones (reservoir-corrected), generated from the shell midden with presence of bones of both terrestrial and marine mammals, fish, and mollusks, allows us to establish the age of this complex as 5800-5400 BP (Kuzmin et al. 2002; Kuzmin 2009).

The Boisman cultural complex (or Boisman "culture" in Russian sources, see below) is divided into several stages (Moreva 2005). The proto-Boisman component with sharp-based vessels recovered from below the shell midden is dated to $7010 \pm 70 \mathrm{BP}$ (SNU-01378) and $7110 \pm 60 \mathrm{BP}$ (AA-60496). The first stage of Boisman culture is dated to $6710 \pm 55 \mathrm{BP}$ (AA-32671), $6635 \pm 60 \mathrm{BP}$ (AA-27534), $6320 \pm 40 \mathrm{BP}$ (AA-60497), and $5840 \pm 40 \mathrm{BP}$ (AA-60498); the second stage to $6150 \pm 40 \mathrm{BP}$ (AA$36384)$ and $5890 \pm 110 \mathrm{BP}$ (AA-60499); the third stage is placed at $5725 \pm 40 \mathrm{BP}$ (AA-36903), $5480 \pm 40 \mathrm{BP}(\mathrm{AA}-36386)$, and $5300 \pm 40 \mathrm{BP}$ (AA-60500); the fourth stage is dated to $5490 \pm 150$ $\mathrm{BP}$ (AA-60501); and the fifth stage can be dated to $5860 \pm 100 \mathrm{BP}$ (AA-60502). Some discrepancies are due to the complicated stratigraphy of the shell midden where artifacts of stages 1-5 of Boisman culture were found. From the bottom of the cultural sequence at the Boisman 2 site with a shell midden, several other ${ }^{14} \mathrm{C}$ values were obtained: $6355 \pm 60 \mathrm{BP}(\mathrm{AA}-9461), 6155 \pm 85 \mathrm{BP}$ (AA-27538), $5560 \pm 50 \mathrm{BP}(\mathrm{AA}-27542), 5465 \pm 50 \mathrm{BP}(\mathrm{AA}-32672), 5380 \pm 50 \mathrm{BP}(\mathrm{AA}-27541), 5330 \pm 55 \mathrm{BP}$ (AA-9460), $5285 \pm 55 \mathrm{BP}(\mathrm{AA}-27537)$, and $5280 \pm 60 \mathrm{BP}(\mathrm{AA}-27543)$.

Two other sites of the Boisman culture (without shell middens) were also dated: Luzanova Sopka 2 at $5840 \pm 40 \mathrm{BP}$ (AA-60498); and Gvozdevo 4 at $5865 \pm 45 \mathrm{BP}$ (AA-60611), $5630 \pm 40 \mathrm{BP}$ (AA60609 ), and $5075 \pm 45 \mathrm{BP}$ (AA-60610). The Boisman 1 site was previously dated using marine mollusk shell to $5690 \pm 45 \mathrm{BP}$ (OS-3030) (see Jones et al. 1996), and this age after reservoir correction (see Kuzmin et al. 2007) corresponds to $\sim 4310-4030 \mathrm{cal} \mathrm{BC}$. An additional ${ }^{14} \mathrm{C}$ value of $5640 \pm 45$ BP (TKa-13484) was obtained from burnt food on a potsherd (Komoto and Obata 2005); its calendar age is $4580-4360$ cal BC.

As for neighboring East Asia, it seems that Japan has the earliest record for use of marine food resources and dates to the Early Holocene, $\sim 9200-7100 \mathrm{BP}$, while in Korea and northeast China the maritime adaptation appeared approximately at the same time as in the Russian Far East, at $\sim 6300$ 5700 BP (see review: Kuzmin 2009). The intensification of marine animal and invertebrate consumption may be related to the high sea level in the Middle Holocene ( $6500-5000$ BP) (e.g. Korotkii 1985; see also Kuzmin 2006a, 2009) and the existence of numerous coastal lagoons with mollusk beds (represented mainly by Pacific oyster, Crassostrea gigas).

\section{The Beginning of Plant Cultivation}

In the early 1990s, little was known about the time when agriculture was introduced in the Russian Far East. There were only 2 sites with direct evidence of Neolithic plant cultivation, i.e. seeds of cultigens: Kirovsky and Novoselische 4 (Kuzmin et al. 1998b). In 2012, we have at least 9 sites with finds of millet seeds from the Late Neolithic cultural components (Table 1, Figure 1). The general age range of the earliest sites with millet seeds is $\sim 4700-3300 \mathrm{BP}$. The single direct ${ }^{14} \mathrm{C}$ date of millet from the Novoselische 4 site, $\sim 3840 \mathrm{BP}$, is noteworthy, and confirms the charcoal ${ }^{14} \mathrm{C}$ values.

Regarding the origin of millet agriculture in the Russian Far East, my current model is that it initially appeared in northern and northeastern China (Cishan site, Hebei Province; and Xinglonggou site, Inner Mongolia Province; see Kuzmin et al. 2009) at around 9200-6300 BP. It then spread to the east and southeast, reaching the southern part of the Korean Peninsula (see Crawford and Lee 2003) and Primorye Province at $\sim 4700-4600$ BP. 
Table 1 Radiocarbon dates associated with the earliest direct traces of millet agriculture in Primorye (Zaisanovka cultural complex).

\begin{tabular}{|c|c|c|c|c|c|}
\hline Site, layer & Material & $\begin{array}{l}{ }^{14} \mathrm{C} \text { date } \\
\text { (BP) }\end{array}$ & Lab nr & $\begin{array}{l}\text { Calendar age } \\
(\text { cal BC) }\end{array}$ & Reference \\
\hline \multirow{2}{*}{$\begin{array}{l}\text { Krounovka } 1, \\
\text { levels } 2-3\end{array}$} & Charcoal & $4670 \pm 30$ & NUTA2-5643 & $3620-3370$ & Komoto and Obata 2004 \\
\hline & Charcoal & $4640 \pm 40$ & Beta-171662 & $3620-3350$ & Komoto and Obata 2004 \\
\hline \multirow[t]{2}{*}{ Mustang } & Charcoal & $4660 \pm 60$ & Ki-3151 & $3630-3200$ & Kuzmin et al. 1994 \\
\hline & Charcoal & $4050 \pm 70$ & $\mathrm{Ki}-3152$ & $2880-2460$ & Kuzmin et al. 1994 \\
\hline \multirow[t]{3}{*}{ Sheklyaevo 7} & Food crust ${ }^{b}$ & $4435 \pm 45$ & AA- 60053 & $3330-2920$ & This paper \\
\hline & Food crust ${ }^{b}$ & $4430 \pm 45$ & AA- 60051 & $3330-2920$ & This paper \\
\hline & Charcoal & $4390 \pm 45$ & AA- 60058 & $3320-2900$ & This paper \\
\hline Kirovsky & Charcoal & $4150 \pm 60$ & Le-193 & $2980-2580$ & Kuzmin et al. $1998 \mathrm{~b}$ \\
\hline Gvozdevo 4 & Food crust ${ }^{b}$ & $4130 \pm 40$ & AA- 60612 & $2870-2580$ & This paper \\
\hline \multirow[t]{2}{*}{ Zaisanovka 1} & Carbonized nut & $4010 \pm 45$ & NUTA2-5282 & $2840-2360$ & Komoto and Obata 2004 \\
\hline & Carbonized nut & $3970 \pm 30$ & NUTA2-5483 & $2570-2350$ & Komoto and Obata 2004 \\
\hline Bogolubovka 1 & Charcoal & $3890 \pm 60$ & SNU07-260 & $2560-2150$ & Garkovik 2008 \\
\hline \multirow[t]{3}{*}{ Novoselishche $4^{c}$} & Charcoal & $3840 \pm 70$ & AA-13400 & $2480-2050$ & Kuzmin et al. $1998 \mathrm{~b}$ \\
\hline & Charcoal & $3755 \pm 35$ & AA-36748 & $2290-2040$ & Kuzmin 2006a \\
\hline & Millet seeds & $3840 \pm 40$ & TKa-14081 & $2460-2150$ & Sergusheva 2008 \\
\hline \multirow{3}{*}{$\begin{array}{l}\text { Rettikhovka- } \\
\text { Geologicheskaya }\end{array}$} & Charcoal & $3390 \pm 55$ & SOAN-4239 & $1880-1530$ & Kolomiets et al. 2002 \\
\hline & Charcoal & $3310 \pm 45$ & SOAN-4240 & $1730-1500$ & Kolomiets et al. 2002 \\
\hline & Charcoal & $3280 \pm 45$ & SOAN-4238 & $1670-1450$ & Kolomiets et al. 2002 \\
\hline
\end{tabular}

${ }^{\mathrm{a} C A L I B}$ 6.0.1 software was used (Reimer et al. 2009) ( $\pm 2 \sigma$, all possible intervals combined and rounded to the next $10 \mathrm{yr}$ ).

b These ages are obtained on food adhesions on the pottery surface, and could be older than contemporaneous charcoal (see Fischer and Heinemeier 2003).

'Samples were collected from the floor of the dwelling.

\section{Other Important Results}

The reservoir age correction values for the Russian Far East were unknown until the mid-1990s when the first date was received (e.g. Jones et al. 1996). After that, more work was done to understand the peculiarities of the reservoir age in the Sea of Japan and Okhotsk Sea (Kuzmin et al. 2007). This was necessary for establishing the true age of the coastal population of Primorye with a heavy marine protein diet (Kuzmin et al. 2002). The reservoir ages obtained by our group are consistent with data generated by Japanese scholars (e.g. Yoneda et al. 2007; Yoshida et al. 2010).

Age determination for individual archaeological sites and cultural complexes [or "cultures" in Russian archaeological terminology; see Trigger (2006:343) and Nelson (2006:4-8)] in the Russian Far East by AMS ${ }^{14} \mathrm{C}$ dating has been conducted continuously since the late $1990 \mathrm{~s}$, and some results are noteworthy. The southern Primorye region, where the majority of archaeological studies are conducted, has the most abundant record of new ${ }^{14} \mathrm{C}$ dates (see Figure 1).

The Early/Middle Neolithic cultural complex initially recognized at the Rudnaya [also known as Rundaya Pristan and Tetukhe] site (e.g. Kuzmin et al. 1994:361-2) was additionally studied in the 2000s. Several ${ }^{14} \mathrm{C}$ values in the range of $\sim 7300-6040 \mathrm{BP}$ were obtained (Batarshev et al. 2010). The earliest extant textile remains in East Asia were dated to $\sim 8215-7710 \mathrm{BP}$ at another site of the Rudnaya culture, Chertovy Vorota (see Kuzmin et al. 2012a). The Middle Neolithic Vetka complex at Sheklyaevo 7 site is dated to $6045 \pm 50 \mathrm{BP}$ (AA-60055) and $5845 \pm 100 \mathrm{BP}$ (AA-60052); the Luzanova Sopka 2 site dates to $5865 \pm 75$ BP (AA-60504). 
The Late Neolithic cultural complex of Zaisanovka was intensively ${ }^{14} \mathrm{C}$ dated in the last few years. Several values were obtained: at Sheklyaevo 7 site, $\sim 4435-4390$ BP; at Gvozdevo 4 site, 4130 BP (Table 1); and at Luzanova Sopka 2, $4770 \pm 40 \mathrm{BP}$ (AA-60505) and $3905 \pm 40 \mathrm{BP}$ (AA-60607). The transitional Neolithic/Paleometal complex of Margaritovo [also known as Margarita, see Cassidy 2007] is now ${ }^{14} \mathrm{C}$ dated to $3605 \pm 35 \mathrm{BP}$ (AA-37114) at the Glazkovka 2 site; to $\sim 3400 \mathrm{BP}$ at the Monastyrka 2 site; $\sim 3600-3500$ BP at the Preobrazheniya 1, Zarya [Zera] 3A, and Zarya 3B sites; and $~ 3420-3340$ BP at the Monastyrka 3 site (Cassidy 2004, 2007).

Several shell middens of the Late Neolithic (Zaisanovka and Klerk cultural complexes) and Early Iron Age were recently ${ }^{14} \mathrm{C}$ dated. The Zaisanovka 7 site of the same culture has several ${ }^{14} \mathrm{C}$ values: $4500 \pm 40 \mathrm{BP}$ (AA-32215); $4470 \pm 40 \mathrm{BP}$ (TKa-13485) (Komoto and Obata 2005); and $4450 \pm$ $40 \mathrm{BP}$ (AA-32217). The Klerk 5 site of the same complex is dated to $4750 \pm 40 \mathrm{BP}$ (TKa-13486) (Komoto and Obata 2005); $4585 \pm 45 \mathrm{BP}$ (TKa-14076) and $4125 \pm 40 \mathrm{BP}$ (TKa-14075) (Obata 2007). The famous Peschany site with a shell midden of the Yankovsky culture (Early Iron Age, see Okladnikov 1965) was dated to $2455-2400$ BP (Cassidy 2007).

In the Amur River basin, significant progress was achieved in the last few years. In the lower part of the Amur River course, a detailed chronological scheme was created (Shewkomud and Kuzmin 2009). In the middle part of the Amur River basin, the age of the main Neolithic complexes is now established (Kuzmin and Nesterov 2010). It is worth mentioning newly released ${ }^{14} \mathrm{C}$ dates for the Late Neolithic Osinoozerskaya culture: $3840 \pm 40 \mathrm{BP}$ (AA-32209) and $3520 \pm 40 \mathrm{BP}$ (AA-60767) at the Mikhailovka-Klyuch site $\left(50^{\circ} 39^{\prime} \mathrm{N}, 127^{\circ} 20^{\prime} \mathrm{E}\right)$; and $\sim 3600-3290 \mathrm{BP}$ at the Gromatukha site, layer 1 (Nesterov et al. 2006).

In the insular regions of the Russian Far East (Figure 1), more ${ }^{14} \mathrm{C}$ dates from prehistoric sites came to light recently. The major chronological patterns of Sakhalin Island are now established (Kuzmin et al. 2004; Vasilevsky et al. 2009, 2010). The earliest pottery from Sakhalin dated at the Puzi 2 [also known as Ado-Tymovo 2 site] site to $\sim 8780-7520$ BP (Kuzmin et al. 2004), and recently to $7215 \pm$ $45 \mathrm{BP}$ (AA-86215). One of the oldest sites in northern Sakhalin, Bolshaya Rechka 7, dates to $6210 \pm$ 40 BP (AA-36905). On the Kurile Islands, the chronology of the main cultural phases has been established (Vasilevsky et al. 2009, 2010; Kuzmin et al. 2012b). The earliest occupation of the southern Kuriles is now securely dated to $\sim 7000 \mathrm{BP}$ at the Yankito site on Iturup Island (Yanshina and Kuzmin 2010).

\section{SOLID FACTS VS. WISHFUL THINKING IN PREHISTORIC CHRONOLOGY OF THE RUSSIAN FAR EAST: AN ANALYSIS}

In studying the geoarchaeology of the prehistoric sites (including chronology) and human-environment interaction in the Russian Far East, several models have been recently published (Vasilevsky 2008; Kuzmin 2009; Vostretsov 2010; Kuzmin and Rakov 2011). Some of these suffer from a wishful thinking approach, where the initial idea put forward by a researcher does not correspond to the factual data. There are discordant aspects among the different models that I would like to note: 1) unsubstantiated claims for the age of prehistoric sites; 2) the emergence of maritime adaptation; 3 ) the beginning of agriculture; and 4) obvious discrepancies. A critique of some of these issues was presented before (Kuzmin 2009, 2011; Kuzmin et al. 2009; Kuzmin and Rakov 2011).

In terms of unproven site ages, the most recent example is the Ogonki 5 site on Sakhalin Island (see Vasilevsky 2006). Six ${ }^{14} \mathrm{C}$ values were received for the Upper Paleolithic component of this site (strata $2 \mathrm{~b}$ and 3), and 5 of them create a tight cluster of $\sim 19,440-17,880 \mathrm{BP}$ (Kuzmin et al. 2004). The sixth value of $31,130 \pm 440 \mathrm{BP}$ (AA-23138) from Stratum 3 was initially accepted (see Kuzmin 
et al. 1998a; Vasilevsky 2006:86), but later was found to be an outlier because of the clearly late Upper Paleolithic nature of the stone tool assemblage with the presence of microblades and wedgeshaped microcores (e.g. Vasilevsky 2006); and a second ${ }^{14} \mathrm{C}$ date of $\sim 17,860 \mathrm{BP}$ from this stratum (Kuzmin 2006a:21). It is difficult to imagine that the microblade technology appeared on Sakhalin Island much earlier than in neighboring Northeast Asia (e.g. Kuzmin 2007). However, Vasilevsky (2008) continued to consider this early ${ }^{14} \mathrm{C}$ value as the true age of Stratum 3. Also, Vasilevsky (2008) claimed that the Upper Paleolithic occupation of Sakhalin Island continued at $\sim 16,000$ 12,000 BP despite the fact that no sites are dated to this timespan (see Kuzmin et al. 2004:355). The Tronnyi Grotto, which is used for this conclusion (see Vasilevsky 2008:238), has no artifacts (see Kuzmin 2011).

As for the origin of maritime adaptation, Vasilevsky (2008; see also Vasilevsky et al. 2010) claimed its beginning on Sakhalin Island at $\sim 9000-6600 / 6000$ BP, although no reliable evidence for this exists (see Kuzmin 2011). Vostretsov $(2006,2010)$ concluded that marine-based economies disappeared in southern Primorye at $\sim 4700-4300$ BP despite the fact that there are several shell middens in this region ${ }^{14} \mathrm{C}$ dated to this time period (e.g. Kuzmin and Rakov 2011:106). The model that I propose is that the first reliable traces of maritime adaptation in the Russian Far East date to $\sim 5800 \mathrm{BP}$, although humans exploited marine resources in limited amounts even earlier, at $7000 \mathrm{BP}$ (see details in Kuzmin 2009).

Some attempts to establish the age of the earliest agriculture in Primorye are unsubstantiated by the data. For example, Vostretsov $(2006,2010)$ connected the beginning of agriculture in southwestern Primorye with an interval of $\sim 5400-5200 \mathrm{BP}$. However, as was repeatedly demonstrated, the oldest site with direct evidence of millet agriculture in the region is dated to $\sim 4700-4600 \mathrm{BP}$ (e.g. Sergusheva 2007, 2008; Kuzmin et al. 2009; also see Table 1). This refutes Vostretsov's (2006, 2010) conclusion.

In some cases, there is a discrepancy in the relationship between climate change (e.g. cooling and regression of the sea) and the intensification of human activity (e.g. maritime strategies): for example, "In the north-west sector of the Japan Sea and eastern Korea, the intensification of maritime adaptation strategies is connected with the cooling and regression of the sea" (Vostretsov 1999:323; italics are mine). Later on, the conclusion was made that the cooling at $\sim 5000 \mathrm{BP}$ is correlated with a decline of maritime-adapted complexes (such as the Boisman culture of southern Primorye) and the appearance of agricultural populations that migrated from neighboring Manchuria (e.g. Vostretsov 2006:28). This aspect needs further study before such conclusions can be stated.

\section{CONCLUSION}

Clearly, more work is still needed to understand the patterns of the chronology of the Paleolithic, Neolithic, and Paleometal complexes of the Russian Far East and neighboring East Asia. One of the most hotly debated current issues is the relationship between cultural and natural changes - for example, the emergence of pottery, agriculture, and maritime adaptation in relation to climatic fluctuations. There is a certain trend to correlate directly the climate changes in the final Pleistocene and Holocene and features of cultural and economic history (emergence of cultural complexes; appearance of new branches of economy). As was shown for the origin of pottery-making in East Asia, there is no reliable evidence for the association between the introduction of pottery vessels and climatic fluctuations after the LGM (Kuzmin 2010). The study of chronology and environment of prehistoric Russian Far East should therefore be carried out without a priori assumptions and biases. 


\section{ACKNOWLEDGMENTS}

I am greatly indebted to Prof A J Timothy Jull (University of Arizona) for fruitful long-term collaboration. My thanks also go to colleagues from Russia (Dr Leopold D Sulerzhitsky, deceased, and Dr Lyobov A Orlova), USA (Drs George S Burr and Dana L Biddulph, and Mr Richard J Cruz), the Netherlands (Dr Johannes van der Plicht), Japan (Drs Minoru Yoneda, Mineo Imamura, and Minoru Sakamoto), and the Republic of Korea (Prof Kim Jong-Chan) for constant support and help. This study was supported by Project "GIS Modeling and Spatial Analysis of Environmental Systems and Their Components" of the SB RAS Program IV.31.2 and Partnership Integrative Project of FEB RAS and SB RAS No. 73. I am grateful to Dr Elisabetta Boaretto (Israel) for the possibility to give an invited talk at the 6th International Symposium "Radiocarbon and Archaeology" (Paphos, Cyprus, 10-14 April 2011), and to an anonymous reviewer for useful suggestions.

\section{REFERENCES}

Batarshev SB, Moreva OL, Kuzmin YV. 2010. The Rundaya Neolithic culture in Primorye: problems of periodization and chronology. Rossiiskaya Arkheologiya 4:5-17. In Russian with English abstract.

Boaretto E, Wu X, Yuan J, Bar-Yosef O, Chu V, Pan Y, Liu K, Cohen D, Jiao T, Li S, Gu H, Goldberg P, Weiner S. 2009. Radiocarbon dating of charcoal and bone collagen associated with early pottery at Yuchanyan Cave, Hunan Province, China. Proceedings of the National Academy of Sciences of the USA 106(24): 9595-600.

Cassidy J. 2004. The Margarita culture of coastal Primorye: an examination of culture change during the Middle Holocene on the northern Sea of Japan [unpublished PhD dissertation]. Santa Barbara: University of California-Santa Barbara. 479 p.

Cassidy J. 2007. A historical and theoretical contextualization of Primorye archaeology. North Pacific Prehistory 1:37-64.

Crawford GW, Lee G-A. 2003. Agricultural origins in the Korean Peninsula. Antiquity 77(295):87-95.

Derevianko AP. 2009. The Middle to Upper Paleolithic Transition and Formation of Homo sapiens sapiens in Eastern, Central and Northern Asia. Novosibirsk: Institute of Archaeology \& Ethnography Press. 328 p. In Russian and English.

Derevianko AP, Tabarev AV. 2006. Palaeolithic of the Primorye (Maritime) Province. In: Nelson SM, Derevianko AP, Kuzmin YV, Bland RL, editors. Archaeology of the Russian Far East: Essays in Stone Age Prehistory. Oxford: Archaeopress. p 41-54.

Derevianko AP, Zenin VN, Shewkomud IY. 2006. Palaeolithic of the Priamurye (Amur River basin). In: Nelson SM, Derevianko AP, Kuzmin YV, Bland RL, editors. Archaeology of the Russian Far East: Essays in Stone Age Prehistory. Oxford: Archaeopress. p 55-73.

Fischer A, Heinemeier J. 2003. Freshwater reservoir effect in ${ }^{14} \mathrm{C}$ dates of food residue on pottery. Radiocarbon 45(3):449-66.

Garkovik AV. 2008. Bogolubovka 1 - pamyatnik pozdnego neolita Primorya [The Bogolubovka 1 - Late
Neolithic site in Primorye]. In: Derevianko AP, Medvedev VE, editors. Okno v Nevedomy Mir. Novosibirsk: Izdatelstvo Instituta Arkheologii i Etnografii. p 131-9. In Russian.

Gladyshev S, Tabarev A, Olsen JW. 2010. Origin and evolution of the Late Paleolithic microindustry in northern Mongolia. Current Research in the Pleistocene 27:38-40.

Goebel T. 2002. The "microblade" adaptation and recolonization of Siberia during the late Upper Pleistocene. In: Elston RG, Kuhn SL, editors. Thinking Small: Global Perspectives on Microlithization. Arlington: American Anthropological Association. p 117-31.

Jones GA, Kuzmin YV, Rakov VA. 1996. Radiocarbon AMS dating of the thermophilous mollusc shells from Peter the Great Gulf coast, Russian Far East. Radiocarbon 38(1):58-9.

Jull AJT, Kuzmin YV, Lutaenko KA, Orlova LA, Popov AN, Rakov VA, Sulerzhitsky LD. 1994. Composition, age and habitat of the Boisman 2 Neolithic site in the Maritime Territory. Doklady Biological Sciences 339: 620-3.

Keates SG. 2007. Microblade technology in Siberia and neighbouring regions: an overview. In: Kuzmin YV, Keates SG, Shen C, editors. Origin and Spread of Microblade Technology in Northern Asia and North America. Burnaby: Archaeology Press. p 125-46.

Kolomiets SA, Batarshev SV, Krutykh EB. 2002. Poselenie Rettikhovka-Geologicheskaya (khronologiya, kulturnaya prinadlezhnost) [The Rettikhovka-Geologicheskaya settlement (chronology, cultural affiliation)]. In: Kradin NN, editor. Arkheologiya i Kulturnaya Antropologiya Dalnego Vostoka. Vladivostok: Dalnevostochnoe Otdelenie Rossiiskoi Akademii Nauk. p 90-102. In Russian.

Komoto M, Obata H, editors. 2004. Krounovka I Site in Primorye, Russia. Report of Excavations in 2002 and 2003. Kumamoto: Department of Archaeology, Kumamoto University. $78 \mathrm{p}$.

Komoto M, Obata H, editors. 2005. Zaisanovka 7 Site in Primorsky, Russia. Preliminary Results of Excavation 
in 2004. Kumamoto: Kumamoto University. 76 p.

Korotkii AM. 1985. Quaternary sea-level fluctuations on the northwestern shelf of the Japan Sea. Journal of Coastal Research 1(3):293-8.

Kuzmin YV. 2003. The Paleolithic-to-Neolithic transition and the origin of pottery production in the Russian Far East: a geoarchaeological approach. Archaeology, Ethnology \& Anthropology of Eurasia 3(15):16-26.

Kuzmin YV. 2006a. Palaeoenvironment and chronology. In: Nelson SM, Derevianko AP, Kuzmin YV, Bland RL, editors. Archaeology of the Russian Far East: Essays in Stone Age Prehistory. Oxford: Archaeopress. p 13-40.

Kuzmin YV. 2006b. Chronology of the earliest pottery in East Asia: progress and pitfalls. Antiquity 80(308): 362-71.

Kuzmin YV. 2007. Geoarchaeological aspects of the origin and spread of microblade technology in Northern and Central Asia. In: Kuzmin YV, Keates SG, Shen C, editors. Origin and Spread of Microblade Technology in Northern Asia and North America. Burnaby: Archaeology Press. p 115-24.

Kuzmin YV. 2009. Prehistoric maritime adaptation on the Pacific coast of Russia: results and problems of geoarchaeological research. North Pacific Prehistory 3:115-39.

Kuzmin YV. 2010. The origin of pottery in East Asia and its relationship to environmental changes in the Late Glacial. Radiocarbon 52(2):415-20.

Kuzmin YV. 2011. Review: Kamenny Vek Ostrova Sakhalin [The Stone Age of Sakhalin Island]. By Aleksander A. Vasilevsky. Journal of Island \& Coastal Archaeology 6(1):167-9.

Kuzmin YV, Nesterov SP. 2010. Khronologiya neoliticheskikh kultur Zapadnogo Priamurya [Chronology of the Neolithic cultures of the Western Amur River basin]. In: Zabiako AP, editor. Traditsionnaya Kultura Vostoka Azii. Vypusk 6. Blagoveshchensk: Izdatelstvo Amurskogo Gosudarstvennogo Universiteta. p 103-10. In Russian.

Kuzmin YV, Rakov VA. 2011. Environment and prehistoric humans on the Russian Far East and neighbouring East Asia: main patterns of interaction. Quaternary International 237(1-2):103-8.

Kuzmin YV, Orlova LA, Sulerzhitsky LD, Jull AJT. 1994. Radiocarbon dating of the Stone and Bronze Age sites in Primorye (the Russian Far East). Radiocarbon 36(3):359-66.

Kuzmin YV, Jull AJT, Sulerzhitsky LD, Orlova LA. 1998a. ${ }^{14} \mathrm{C}$ chronology of Stone Age cultures in the Russian Far East. Radiocarbon 40(2):675-86.

Kuzmin YV, Jull AJT, Jones GA. 1998b. Early agriculture in Primorye, Russian Far East: new radiocarbon and pollen data from Late Neolithic sites. Journal of Archaeological Science 25(8):813-16.

Kuzmin YV, Baryshnikov GF, Jull AJT, Orlova LA, van der Plicht J. 2001. Radiocarbon chronology of the Pleistocene fauna from Geographic Society Cave, Pri- morye (Russian Far East). Current Research in the Pleistocene 18:106-8.

Kuzmin YV, Richards MP, Yoneda M. 2002. Palaeodietary patterning and radiocarbon dating of Neolithic populations in the Primorye Province, Russian Far East. Ancient Biomolecules 4(2):48-53.

Kuzmin YV, Vasilevski AA, Gorbunov SV, Burr GS, Jull AJT, Orlova LA, Shubina OA. 2004. Chronology of prehistoric cultural complexes of Sakhalin Island (Russian Far East). Radiocarbon 46(1):353-62.

Kuzmin YV, Petrov VG, Kim J-C. 2005. Timing of the origin of microblade technology in the Russian Far East: chronology of the Khodulikha 2 Upper Paleolithic site. Current Research in the Pleistocene 22:79.

Kuzmin YV, Burr GS, Gorbunov SV, Rakov VA, Razjigaeva NG. 2007. A tale of two seas: reservoir age correction values $(R, \Delta R)$ for the Sakhalin Island (Sea of Japan and Okhotsk Sea). Nuclear Instruments and Methods in Physics Research B 259(1):460-2.

Kuzmin YV, Jull AJT, Burr GS. 2009. Major patterns in the Neolithic chronology of East Asia: issues of the origin of pottery, agriculture, and civilization. Radiocarbon 51(3):891-903.

Kuzmin YV, Keally CT, Jull AJT, Burr GS, Klyuev NA. 2012a. The earliest surviving textiles in East Asia from Chertovy Vorota Cave, Primorye Province, Russian Far East. Antiquity 86(332):325-37.

Kuzmin YV, Yanshina OV, Fitzpatrick SM, Shubina OA. 2012b. The Neolithic of the Kurile Islands (Russian Far East): current state and future prospects. Journal of Island \& Coastal Archaeology 7(2):234-54.

Kuznetsov AM. 2010. Review: Origin and Spread of Microblade Technology in Northern Asia and North America /Eds. Y.V. Kuzmin, S.G. Keates, C. Shen. Archaeology Press, Simon Fraser University, Burnaby, B.C. 2007. 222 p. Rossiiskaya Arkheologiya 3:16971. In Russian.

Moreva OL. 2005. Keramika Boismanskoi Kultury (po Materialam Pamyatnika Boismana-2) [The Pottery of Boisman Culture (Based on Materials from the Boisman 2 Site)]. Synopsis of the Candidate of Historical Sciences Dissertation. Vladivostok: Dalnevostochny Gosudarstvenny Universitet. 25 p. In Russian.

Morlan RE. 1967. Chronometric dating in Japan. Arctic Anthropology 4(2):180-211.

Nelson SM. 2006. Introduction. In: Nelson SM, Derevianko AP, Kuzmin YV, Bland RL, editors. Archaeology of the Russian Far East: Essays in Stone Age Prehistory. Oxford: Archaeopress. p 3-11.

Nesterov SP, Sakamoto M, Imamura M, Kuzmin YV. 2006. The Late-Glacial Neolithic complex of the Gromatukha site, Russian Far East: new results and interpretations. Current Research in the Pleistocene 23: 46-9.

Obata H, editor. 2007. Klerk 5 Site in Primorsky, Russia. Preliminary Results of Excavation in 2005. Kumamoto: Kumamoto University. 54 p. 
Okladnikov AP. 1965. The Soviet Far East in Antiquity: An Archaeological and Historical Study of the Maritime Region of the USSR. Toronto: University of Toronto Press. 280 p.

Okladnikov AP, Medvedev VE. 1983. Issledovanie mnogosloinogo poseleniya Gasya na Nizhnem Amure [The study of multilayered settlement of Gasya in the Lower Amur River]. Izvestiya Sibirskogo Otdeleniya Akademii Nauk SSSR. Seriya Obshchestvennykh Nauk 1:93-7. In Russian.

O'Malley JM, Kuzmin YV, Burr GS, Donahue DJ, Jull AJT. 1999. Direct radiocarbon accelerator mass spectrometry dating of the earliest pottery from the Russian Far East and Transbaikal. Mémoires de la Société Préhistorique Française 26:19-24.

Reimer PJ, Baillie MGL, Bard E, Bayliss A, Beck JW, Blackwell PG, Bronk Ramsey C, Buck CE, Burr GS, Edwards RL, Friedrich M, Grootes PM, Guilderson TP, Hajdas I, Heaton TJ, Hogg AG, Hughen KA, Kaiser KF, Kromer B, McCormac FG, Manning SW, Reimer RW, Richards DA, Southon JR, Talamo S, Turney CSM, van der Plicht J, Weyhenmeyer CE. 2009. IntCal09 and Marine09 radiocarbon age calibration curves, 0-50,000 years cal BP. Radiocarbon 51(4): 1111-50.

Renfrew C, Bahn P. 2004. Archaeology: Theories, Methods, and Practice. 4th edition. New York: Thames \& Hudson. $656 \mathrm{p}$.

Sergusheva EA. 2007. The early agriculture in Primorye. Vestnik Dalnevostochnogo Otdeleniya Rossiiskoi Akademii Nauk 15(3):116-20. In Russian with English abstract.

Sergusheva EA. 2008. Poyavlenie zemledeliya na territorii yuzhnogo Primorya [The appearance of agriculture in southern Primorye]. In: Popov AN, editor. Neolit i Neolitizatsiya Basseina Yaponskogo Morya: Chelovek i Istorichesky Landshaft. Vladivostok: Izdatelstvo Dalnevostochnogo Universiteta. p 205-17. In Russian with English summary.

Shewkomud IY, Kuzmin YV. 2009. Khronologiya kamennogo veka Nizhnego Priamurya (Dalny Vostok Rossii) [Stone Age Chronology of the Lower Amur River basin (Russian Far East)]. In: Shewkomud IY, editor. Kulturnaya Khronologiya i Drugie Problemy v Issledovaniyakh Drevnostei Vostoka Azii. Khabarovsk: Khabarovsky Kraevoi Muzei. p 7-46. In Russian.

Trigger BG. 2006. A History of Archaeological Thought. 2nd edition. Cambridge: Cambridge University Press. $710 \mathrm{p}$.

Vasilevsky AA. 2006. The Upper Palaeolithic of Sakhalin Island. In: Nelson SM, Derevianko AP, Kuzmin YV, Bland RL, editors. Archaeology of the Russian
Far East: Essays in Stone Age Prehistory. Oxford: Archaeopress. p 75-100.

Vasilevsky AA. 2008. Kamenny Vek Ostrova Sakhalin [The Stone Age of Sakhalin Island]. Yuzhno-Sakhalinsk: Sakhalinskoe Knizhnoe Izdatelstvo. 412 p. In Russian.

Vasilevsky AA, Grischenko VA, Kuzmin YV, Orlova LA. 2009. Khronologiya i periodizatsiya epokhi neolita na Sakhaline i Kurilskikh ostrovakh (po dannym radiouglererodnogo datirovaniya) [Chronology and periodization of the Neolithic epoch on Sakhalin Island and Kurile Islands (by data on radiocarbon dating)]. In: Shewkomud IY, editor. Kulturnaya Khronologiya $i$ Drugie Problemy $v$ Issledovaniyakh Drevnostei Vostoka Azii. Khabarovsk: Khabarovsky Kraevoi Muzei. p 74-82. In Russian.

Vasilevsky AA, Grischenko VA, Orlova LA. 2010. Periods, boundaries, and contact zones in the Far Eastern insular world of the Neolithic (based on the radiocarbon chronology of sites on the Sakhalin and Kuril Islands). Archaeology, Ethnology \& Anthropology of Eurasia 38/1:10-25.

Vostretsov YE. 1999. Interaction of maritime and agricultural adaptations in the Japan Sea basin. In: Gosden C, Hather J, editors. The Prehistory of Food: Appetites for Change. New York: Routledge. p 322-32.

Vostretsov YE. 2006. Turning points in the cultural evolution of prehistoric Primorye. Archaeology, Ethnology \& Anthropology of Eurasia 3(27):25-32.

Vostretsov YE. 2010. Primorskie Okhotniki-Sobirateli $i$ Zemledeltsy Basseina Yaponskogo Morya: Adaptatsiya i Vzaimodeistvie v Srednem i Pozdnem Golotsene (6500-1800 Let Nazad) [Maritime HunterGatherers and Agriculturalists of the Sea of Japan Basin: Adaptation and Interaction in the Middle and Late Holocene (6500-1800 Years Ago)]. Synopsis of the Doctor of Historical Sciences Dissertation. St. Petersburg: Institut Istorii Materialnoi Kultury Rossiiskoi Akademii Nauk. 54 p. In Russian.

Yanshina OV, Kuzmin YV. 2010. The earliest evidence of human settlement in the Kurile Islands (Russian Far East): the Yankito site cluster, Iturup Island. Journal of Island \& Coastal Archaeology 5(1):179-84.

Yoneda M, Uno H, Shibata Y, Suzuki R, Kumamoto Y, Yoshida K, Sasaki T, Suzuki A, Kawahata H. 2007. Radiocarbon marine reservoir ages in the western $\mathrm{Pa}$ cific estimated by pre-bomb molluscan shells. $\mathrm{Nu}$ clear Instruments and Methods in Physics Research $B$ 259(1):432-7.

Yoshida K, Hara T, Kunikita D, Miyazaki Y, Sasaki T, Yoneda M, Matsuzaki H. 2010. Pre-bomb marine reservoir ages in the western Pacific. Radiocarbon 52(3): 1197-206. 